\title{
Historiography of Coastal Communities in Indonesia
}

\author{
Endang Susilowati \\ Department of History, Faculty of Humanities, Diponegoro University, Indonesia
}

DOI: https://doi.org/10.14710/jmsni.v3i2.6261

\begin{abstract}
This article examines the development of the historiography of coastal communities in Indonesia and suggested interesting themes that can be developed. A contradictory situation in which Indonesia as a great maritime nation with a large number of coastal villages where tens of millions of people live in, dominantly they are fishing communities and sea tribes. However, historiography about coastal communities is still a few in number. To date, the historiography of Indonesia's maritime focuses more on sailing, trading, and port activities. The historiography of coastal communities as a part of maritime history studies has not

Received:

November 5, 2019

Accepted:

December 8, 2019

Corresponding Author:

esaruben84@gmail.com

been widely conducted. A published dissertation by Masyhuri (1996) on the socio-economic lives of fishermen on the north coast of Java became the first study on the lives of coastal communities in Indonesia. Several other studies such as the study conducted by Widodo (2005), Kesuma (2004), Alimuddin (2005), Vickers (2009), Hamid (2011) and Suyuti (2011) are some examples of the historiography of coastal communities. Through the bibliographical study it is found that the lack of historiography of coastal communities due to limited written sources because of the absence of writing tradition among these communities. However, along with the development of historical methodology, historical sources are no longer dependent solely on written sources, thus studies on the historiography of coastal communities have started to be carried out.
\end{abstract}

Keywords: Maritime Historiography; Coastal Communities.

\section{Introduction}

The late A.B. Lapian, a maestro of Indonesian maritime history, on one occasion stated that the study of maritime history had no sound. Such statement was an expression of concern because Indonesian maritime historiography and culture had not been widely explored, while Indonesian waters are almost $2 / 3$ of the total area of Indonesia. As an archipelagic state having thousands of islands, Indonesia provides a very broad field of studies in maritime, including maritime history and culture. Nonetheless, to date, it has not been much explored by Indonesian historians. This is obvious especially when compared with historical studies in other aspects such as rural and agrarian history, economic history, social history, and political history -some fields which have attracted many historians. Not to mention when compared to the development of the studies of maritime history in other countries, such as the Netherlands of which the area is even smaller than the East Java Province, but pays much attention to its maritime. This is evident from the fact that it has a large collection of books related to maritime field, including books on Dutch maritime history. Further, there are many Dutch historians who also focused on the study of Indonesian maritime history such as J.C. van Leur, Heather Sutherland, Gerrit J. Knaap, Luc Nagtegaal, etc.

In the last two decades, some works on Indonesian maritime history written by Indonesian historians have started to emerge. However, these studies only focus on sailing and trade aspects, and port development, while the study of coastal communities has not yet received much attention from historians. It is certainly a concern that the historiography of coastal community is still rarely found. Sartono Kartodirdjo once emphasized the importance of the historiography of farmers and ordinary people in suburban areas, an aspect which is often forgotten in history, and A.B. Lapian added to such statement by mentioning that what is forgotten is not only those who live on land but also those who live close to the sea (Lapian 2009, 282). Lapian's statement implies the 
importance of not only studying maritime aspects in general, but also studying the people whose activities are mainly in the sea and coastal area.

This article aims to describe the development of the historiography of coastal communities in Indonesia, an aspect which has not been much explored compared to other aspects of historical studies. The study of coastal communities has indeed not received much attention compared to other studies of rural or urban communities. This is possibly due to the lack of accessible writing sources or the absence of methodology that can be used to discuss some problems related to the history of coastal communities. This way, this article also tries to map the problems related to sources and methodology in relation to the study of coastal communities in Indonesia, as well as interesting themes that can be brought up. This study used bibliographical method to find works on Indonesian maritime history that were published in the last two decades. Through this method it was found that the number of studies on the history and culture of coastal communities was fewer than the study of maritime history in general. From that fact further research was done to understand the cause.

\section{Coastal Area and Coastal Community}

According to Kamus Besar Bahasa Indonesia, the word 'pesisir' (coast) refers to sandy flat land on the beach or the seashore (Kamus Besar Bahasa Indonesia Online (https://kbbi.web.id/pesisir). However, the definition of coastal area is of course not limited to sandy flat land on the seashore, but it can be broader than that. Coastal area can also be defined as an area where land meets the sea; to the direction of land including the land, both dry and water, which is still affected by sea characteristics such as tides, sea breezes and saltwater seepage; while to the direction of the sea including the parts of the sea that are still affected by natural processes that occur on land such as sedimentation and fresh water, or by human activities on land such as deforestation and pollution (Bengen 2002).

Meanwhile, coastal community is defined as a group of people who live together in a coastal area and form and have a distinctive culture related to their dependence on the use of coastal resources (Satria 2015). In other words, coastal communities are people who inhabit a coastal area and their main source of living relies on marine and coastal resources. Based on this definition, it can be said that coastal communities are not only fishermen, but also fish farmers, salt farmers, fish processors, fish traders or sellers, boat makers, sailors, etc.

\section{Development of Historiography of Coastal Communities}

In the context of maritime historiography, the presence of coastal communities is still overlooked by historians. There are not many historical studies that discuss the history of coastal community lives, let alone the history of marginalized groups's lives, compared to those of agrarian-based rural groups. Using a term introduced by Antonio Gramsci, coastal communities as mentioned above can be included in the subaltern group. Generally they do not have access to power; they even do not have enough access to history, to their own representation, nor to social and cultural institutions (Wirawan 2010, 522). Such groups are often forgotten in history. This is evident from the lack of historical works that describe who they are or how they live in a certain period.

A work by Masyhuri entitled Menyisir Pantai Utara Jawa (1996) is one of few historical works on coastal communities and their economic activities. In this published dissertation, Masyhuri put more emphasis on the history of fisheries in the socio-economic aspect, compared to the description of the community (fishermen in the north coast of Java and Madura). Even so, such work of Masyhuri can be said to have started the writing of the history of coastal communities. Prior to such work, there seems to be no historical study of fisheries and fishing communities. The studies on fishing communities are mostly found from other fields of study such as maritime anthropology, economic anthropology, and sociology. 
By using archive and document sources, Masyhuri describes many aspects including fish trade network so as to reveal the position and role of fishermen, fish sellers, retailers, sea skipers, and inland skippers in the economic activities in coastal areas in the late 19th century. The position of fishermen in the social stratification of community is mainly influenced by fishing organizations and their level of income. When they have more important and more strategic position in fishing organizations and greater income, they have more opportunity to occupy high positions in social stratification. On the other hand, when they have less important position in fishing organization and lower income, they are likely to occupy less important position in the stratification of coastal communities. In this context, inland skippers are members of coastal community who occupy the highest position because they are usually the ship owners or people who have capital in fishing activities. Masyhuri finally came to the conclusion that the level of fishermen welfare is determined not solely by the level of development of fishing sector, but by their involvement in fish marketing activities.

The confusion that Masyhuri had when he started writing his book due to the scarcity of historical research on fisheries and fishing communities in Indonesia that could be used as a reference or model no longer becomes a problem for future researchers. Masyhuri's work has also encouraged more historical studies of fisheries and fishing communities, one of which was conducted by Sutejo K. Widodo (2005). Focusing on port development, from a commercial port to a fishing port, Sutejo adopted a narrower spatial scope (Pekalongan) and temporal scope of the XX century. He also made efforts to reveal the history of fisheries and the lives of fishermen after the changes or development of Pekalongan fishing port, from an ordinary fishing port to a Nusantara (national) fishing port.

Almost similar to Masyhuri, Sutejo also conducted a study of the history of fisheries in terms of the socio-economic aspect. He ended his article with a statement that it is still necessary to conduct studies of the history of fisheries and fishing communities. It is necessary to bring up specific themes, such as the patterns of the economic activities of fishermen during the 1930 worldwide economic depression or the development of fisheries sector associated with regional autonomy, in order to enrich maritime historiography, especially the historiography of coastal communities.

Unlike Masyhuri and Sutejo who focused on the socio-economic aspects of the coastal communities in Java and Madura, Andi Ima Kesuma examined the diaspora of Bugis Wajo community (Kesuma 2004). This study confirmed that Bugis community had dispersed since the 17 th century due to at least two factors, namely economic and non-economic factors such as the absence of peace caused by war or the loss of independence. The last driving factor of diaspora is closely related to the philosophy of the Bugis Wajo community as meant by the saying "Maradeka to-Wajo'e ade'mi napopuwang" (The people of Wajo are independent, only laws are upheld). If the government does not uphold law enforcement, Bugis people will leave their region and live in another region as a form of protest to the government which is considered ignorant of the law (Kesuma 2004, ix). By using the theories and concepts of diaspora from social science disciplines, Andi Ima Kesuma wanted to reveal the motives, reasons, and effects of the migration of Bugis people to other islands or regions.

Although not all Bugis people live in coastal areas, this book still adds to the historiography of coastal areas, considering the fact that the activities of Bugis people, who are generally migrants, are in contact with coastal areas where they meet various other ethnic groups in the regions they come to (usually coast or island). As recorded in the history, the Bugis diaspora is not limited to various regions in this country, but also to foreign countries. This had started since the $17^{\text {th }}$ century due to the war between the VOC and Makassar, especially after the fall of Benteng Somba Opu and the take over of the capital of the Wajo kingdom which was an ally of the Makassar and Luwu kingdom.

Adrian Vickers in his book entitled Peradaban Pesisir (2009) described cerita panji as a result of coastal culture which exists not only in Indonesia but also in other countries in the Southeast Asia. Cerita panji can serve as a collective memory for the nations in the Southeast Asia who 
formally have the same political and geographical ties. According to Vickers, various ethnic groups in the Southeast Asia only have loose bond through trade, while they actually have the experience of sharing the same history. This is evident by the existence of cerita panji which is not only found among the Malays, Javanese or Thais, but also found evenly throughout the regions, beyond the boundaries of the existing narrow ties (Vickers 2009, xiv). A very important Balinese poem in the $18^{\text {th }}$ and $19^{\text {th }}$ centuries, namely Malat, shows the existence of intensive intercultural interaction which can prove that the various cultures existing in the Southeast Asia are manifestation of a shared civilization, which is usually referred to as coastal civilization.

Another work on coastal communities and culture is written by Muhammad Ridwan Alimuddin entitled Orang Mandar Orang Laut (2005). Alimuddin was not a historian, but as a young man from Mandar who was very close to the maritime culture, he had the ability to describe the historical aspects of the life of the Mandar people. In the foreword of this book, A.B. Lapian stated that, although this book is simple, it presents abundant information about coastal culture which has not widely known (Alimuddin 2005, xi).

This book, written as a record of journey, describes various aspects of Mandar's maritime culture including various pre-sailing activities, ceremonies carried out when starting to sail a boat across an ocean, various knowledge needed to go sailing, how to catch fish, even how to divide the fish catch among ship's crew.

For historians interested in maritime history, Alimuddin's writing is quite important because it records the maritime life of the Mandar people. This book describes at least three aspects of Mandar maritime culture, namely the boat sande' (traditional Mandar boat) and various traditions accompanying it; the motangnga tradition, i.e. the tradition of drifting into the middle of the sea to catch increasingly-rare flying fish; and the marroppong tradition, i.e. fishing using roppong (rumpon). This work of Alimuddin was written mainly based on his observations in a number of fishing villages on the coast of the Mandar bay from 2001 to 2003, supported by various relevant research findings.

Bringing up maritime ethnic groups, the work of Abd. Rahman Hamid entitled Orang Buton. Suku Bangsa Bahari Indonesia (2011) may add to the historiography of coastal communities. This book describes the life processes of the coastal communities in Wakatobi Island (Wangi-wangi, Kaledupa, Tomia, and Binongko) in dealing with various challenges and problems. Together with the Javanese, Madurese, Banjar, Mandar, Bugis, etc, the Butonese people also participated in building a trading network in the Java Sea since several centuries ago. Unlike other works of Buton history which focus more on the power or history of kingdom yet less on sailing and trade activities as well as the maritime life of the Butonese, this book tries to reveal another aspect of Buton history, i.e. the maritime life of the Wakatobi people which was almost forgotten in the Buton history. Therefore, as expected by the author, it can reveal the history of the lower classes (maritime communities), coastal communities, or the history of marginalized people.

Various historical sources regarding the activities of the Butonese, especially the Wakatobi people, in terms of their maritime life, collected by the author of this book are not only in the form of archives, documents, scientific articles, and books or relevant research findings. The sources used in writing this book are also in the form of oral sources or the results of interviews with informants, including people experiencing the maritime history in Wakatobi and other informants who were competent with the focus of this study.

The last book collected in a short period of time to complete the description of the historiography of coastal communities is one written by Nasruddin Suyuti entitled Orang Bajo di Tengah Perubahan (2011). A professor of social science at Haluoleo University, who pursued his master degree in anthropology at the University of Indonesia, tried to reveal the maritime life of a maritime tribe, namely Bajo tribe. As time goes by, the Bajo tribe has dealt with various changes. In 1982 the government of Indonesia made efforts to "land" the Bajo tribe in order to "civilize" them and to "inculcate" them, and since then, the Bajo tribe had to face various changes because they had been accustomed to living in synergy with the sea for long time. 
In this book, Suyuti focused more on the changes that originated from within the Bajo people themselves, i.e. changes to the concept of sama (Bajo people) and bagai (not Bajo people). Nasrudin considered these concepts as a symbol that distinguishes between "Bajo" and "Not Bajo" and at the same time as a symbol of life at sea and inland (Suyuti 2011,3). According to Suyuti, the process of change in the meaning of sama and bagai shows a change in the Bajo people's lives, who no longer distinguish themselves (sama) from the Bugis (bagai). It is also possible that as time goes by, the Bajo people will also no longer feel different from other coastal people who also depend most of their lives on marine resources.

\section{Problems Related to Sources and Methodology}

It has to be admitted that, to date, there is still an assumption that, to write maritime history, there are many difficulties related to its historical sources and methodology. The scarcity of resources, the difficulty in finding them, and the high costs to obtain these sources are some of the problems faced by not only students but also lecturers and other researchers. A.B. Lapian also stated that the temporal scope of his pirate-related study in the Sulawesi Sea should be limited to the nineteenth century only, because the historical sources from this century were more available than those from previous centuries (Lapian 2009, 7). In addition, these sources were also mostly foreign sources; many were available from the nineteenth century because at that time there were many Western ships visiting the Sulawesi Sea. Meanwhile, local or indigenous sources related to the problem brought up by Lapian were very few in number, especially for primary sources.

In the context of the historiography of coastal communities, there are not many written sources or documents as historical evidence. During the colonial era, the activities of the indigenous people were of course not recorded in the archives and documents of the colonial government, except when there were certain incidents involving the indigenous people and the interests of the colonial government, for examples when there was rebellion or any events that might disturb the power of the colonial government. However, this should not be considered as an obstacle to reconstructing the history of coastal communities. In fact, there are quite many traditional sources produced by the ethnic groups in the archipelago which serve as Indonesian traditional historiography sources.

Adrian Vickers used cerita panji from Bali as a material to describe the conditions that led to the so-called coastal civilization not only in Bali, but by finding similarities, this can also be applied for almost all the regions in the Southeast Asia. Bambang Purwanto also confirmed that, to reconstruct the past into history, a variety of sources is required (Vickers 2009, xvii). In fact, historical sources are not limited to only written documents, especially colonial documents, but can also be in the form of oral traditions, paintings, chronicles or dynastic chronicles, and, equally important, literary works produced by a community at a certain period of time. Literary works are closely related to history because these works serve as an identity or social picture of a community at a certain time. According to Kuntowijoyo, literature is not history, but historians are allowed to use literary works, which serve as a reflection of daily lives, as one source of history along with other conventional sources to write history (Purwanto 2008, 246). This way, it is possible to write about the history of community, the history of ordinary people, and the social history of daily lives that are rarely brought up.

In relation to the history of coastal communities, problems related to writing source really exist. The scarcity of historical works on coastal communities written by Indonesians is also caused by the lack of available writing sources. The absence of writing tradition in most coastal communities has made many of their past activities not recorded. Even if ancient texts, for example Rambang (Tegal), were found, the readability level was low. This is not only because the physical condition of the manuscript was fragile, but also because the users' ability to understand the language in the manuscript was usually very limited.

The difficulty in obtaining writing sources should not hinder someone who intends to write the history of coastal communities, especially if the problem to be brought up is contemporary. 
Methodological development and perspective changes in writing the history of communities have allowed historians to use various writing sources, which consist of not only written sources, but also various other sources that could provide information about events in the past. For example, writing about the history of female fishermen or the wives of fishermen can reveal their activities when their husbands were gone sailing, how they managed their household or raised their children, what they did to fulfill their daily needs, how they socialized with their neighbors, etc. To reconstruct all these, it is impossible to depend on written sources. This way, other available sources are needed, including oral traditions or folklore about daily lives in fishing villages, photographs and paintings of fishing villages, or markets in fishing villages. In addition, writing sources obtained through oral history method are also very important.

Oral tradition is different from oral history. Oral tradition is an oral testimony transfered verbally from one generation to the following generations. Oral tradition is only limited to the oral culture of illiterate communities and it is a historical source that records the past, similar to documents in literate communities (Kuntowijoyo 2003, 25). Unlike oral tradition, oral history cannot be obtained, but sought after intentionally through interviews. By using correct interview technique, oral information can be reliable. An interesting example of how oral traditions are used in coastal historiography is a study conducted by Suliyati and Rochwulaningsih (2019).

To explore the writing sources of the history of coastal communities, in my opinion, oral history is one appropriate method to collect sources. Considering the fact that not all maritime or coastal communities have their own historical records and that official sources are also not likely to exist (there are not many competent parties that document past events of coastal communities), thus, in addition to using modern sources such as photographs, paintings and other relics (if any), the results of interviews can be a reliable historical source. Nonetheless, doing oral history method requires specific abilities. To dig someone's memories of the past events requires the right ways and time, so as to obtain information with a high degree of accuracy.

\section{Interesting Themes to be Developed}

In writing the history of coastal communities, there are certainly many interesting themes to be developed. Apart from the adequacy of available resources, several major themes, which can still be broken down into smaller and more diverse themes, may be proposed. Some of the interesting major themes are fishing communities, sea tribes and coastal culture.

The theme related to fishing community can be broken down into smaller themes, for examples about the life of fishermen who have to sail across the sea; about fish traders who play an important role in the distribution of fishermen's catches; about community groups who make salted fish, pindang (a type of processed fish), shrimp paste, fish crackers; and about fish farmers or salt farmers. Another example is the history of female fishermen / fishermen's wives or children who help lift fish baskets from boats to land; etc. Themes about common people or ordinary people in coastal communities have not been widely written due to limited resources, but these themes now increasingly gain more attention. Coastal historiography can also focus on women's lives, one aspect that is often forgotten in historical studies. One interesting example of this issue is the study conducted by Wardojo (2019).

The theme related to sea tribe can also be broken down into many smaller themes, for examples, about their activities related to their livelihoods such as fishing, catching sea cucumber, planting seaweed, etc. Other themes related to the wandering habits of these sea tribes are also interesting to study, especially in relation to their encounters with other tribes and the interactions that occur among them. In addition, the history of the boat-making community is also a very interesting theme to write.

Coastal culture themes are probably the most likely to be written because these themes are not only very interesting but also providing adequate writing sources, considering the fact that these themes are often studied by anthropologists, literary writers, and historians. The themes of coastal culture can also be broken down into smaller themes, for examples about coastal folklore, coastal 
dance or music, traditions, customs, rituals, etc. These themes can certainly be more diverse given the fact that the coastal communities in Indonesia have a rich variety of cultures and traditions, some of which are still well maintained and relevant to their lives at the present.

\section{Conclusion}

Until the present time, the history of coastal communities has been overlooked by maritime historians for various abovementioned reasons. Thus it is time to pay equal attention to the study of other maritime historical fields, such as trade, sailing, ports, piracy, and etc. It is necessary to write about the history of community or the history of ordinary people along with the development of a variety of sources and methodologies that can be used.

There is one good thing, i.e. there are recently more historians who are interested in "plunging into the sea", "sailing across the ocean", "sailing across islands", and "wandering around the coast and sea" to be able to photograph every detail of the coastal communities' activities, so as to add to the historiography of coastal communities and the historiography of maritime in general. Therefore, the study of maritime history and culture will no longer have no sound as the maestro once experienced.

\section{References}

Alimuddin, Muhammad Ridwan. 2005. Orang Mandar Orang Laut. Jakarta: Perpustakaan Populer Gramedia/Yayasan Adikarya IKAPI.

Bengen, D.G. 2002. "Ekosistem dan Sumberdaya Alam Pesisir dan Laut serta Prinsip Pengelolaannya”. Sinopsis. Pusat Kajian Sumberdaya Pesisir dan Lautan IPB.

Hamid, Abd. Rahman. 2011. Orang Buton. Suku Bangsa Bahari Indonesia. Yogyakarta: Penerbit Ombak.

Kamus Besar Bahasa Indonesia Online (https://kbbi.web.id/pesisir), accessed in 15 November 2017 Kesuma, Andi Iwa. 2004. Migrasi dan Orang Bugis. Yogyakarta: Penerbit Ombak.

Kuntowijoyo. 2003. Metodologi Sejarah. Yogyakarta: PT. Tiara Wacana.

Lapian, Adrian B. 2009. Orang Laut, Bajak Laut, Raja Laut. Sejarah Kawasan Laut Sulawesi Abad $X I X$. Jakarta: Komunitas Bambu.

Masyhuri. 1996. Menyisir Pantai Utara: Usaha dan Perekonomian Nelayan di Jawa dan Madura 1850-1940. Yogyakarta: Yayasan Pustaka Nusantara \& KITLV.

Purwanto, Bambang. 2008. "Menulis kehidupan sehari-hari Jakarta. Memikirkan kembali sejarah sosial Indonesia" in Perspektif Baru Penulisan Sejarah Indonesia, edited by Henk Schulte Nordholt, Bambang Purwanto, and Ratna Saptari. Jakarta: Yayasan Obor Indonesia, KITLVJakarta, Pustaka Larasan.

Satria, Arif. 2015. Pengantar Sosiologi Masyarakat Pesisir. Jakarta: Yayasan Pustaka Obor Indonesia.

Suliyati, Titiek and Yety Rochwulaninsih. 2019. "Social Changes and Strategies for Bugis Ethnic Cultural Retention in Karimunjawa." Journal of Maritime Studies and National Integration, 3 (1), 14-21, Jul, 2019. https://doi.org/10.14710/jmsni.v3i1.3531.

Suyuti, Nasruddin. 2011. Orang Bajo di Tengah Perubahan. Yogyakarta: Penerbit Ombak.

Vickers, Adrian. 2009. Peradaban Pesisir. Menuju Sejarah Budaya Asia Tenggara. Denpasar: Pustaka Larasan/Udayana University Press.

Wardojo, Waskito Widi. 2019. "Poverty and Women Status among the Fishers Community in Contemporary Era". Journal of Maritime Studies and National Integration, 3 (1), 45-53, Jul, 2019. https://doi.org/10.14710/jmsni.v3i1.5424.

Widodo, Sutejo K. 2005. Ikan Layang Terbang Menjulang. Semarang: Badan Penerbit Universitas Diponegoro. 
Wirawan, Wahyu. 2010. "Historiografi Aliran Subaltern." In Sejarah Indonesia: Perspektif Lokal dan Global. Persembahan 70 Tahun Prof. Dr. Djoko Suryo, edited by Sri Margana and Widya Fitrianingsih. Yogyakarta: Penerbit Ombak. 